\title{
Reviewer Acknowledgements for Global Journal of Health Science, Vol. 10, No. 12
}

Global Journal of Health Science wishes to acknowledge the following individuals for their assistance with peer review of manuscripts for this issue. Their help and contributions in maintaining the quality of the journal are greatly appreciated.

Global Journal of Health Science is recruiting reviewers for the journal. If you are interested in becoming a reviewer, we welcome you to join us. Please find the application form and details at http://recruitment.ccsenet.org and e-mail the completed application form to gjhs@ccsenet.org.

\section{Reviewers for Volume 10, Number 12}

Abdulbari Bener, Istaanbul University, Turkey

Althea Jane Gamble Blakey, University of Otago, New Zealand

Ama Pokuaa Fenny, University of Ghana, Ghana

Amy E Jetton, Middle Tennessee State University Murfreesboro, United States of America

António Calha, Polytechnic Institute of Portalegre, Portugal

Ayesha Johnson, University of South Florida, United States of America

Basak Baglama, Near East University, Cyprus

Darampal Dambhare, Mahatma Gandhi Institute of Medical Sciences, India

Diadie Maiga, Management Sciences for Health in Arlington, United States of America

Emad Adel Shdaifat, Imam Abdulrahman Bin Faisal University, Saudi Arabia

Farahnaz Amini, UCSI University, Malaysia

Francisco Rodenas Rigla, University of Valencia, Spain

Gavric Zivana, University Banja Luka, Bosnia and Herzegovina

Hülya YARDIMCI, Ankara University, Turkey

Jason Tsai, Lincoln College, United Kingdom

Jichuan Wang, The George Washington University, United States of America

José Joaquín Mira, Universidad Miguel Hernández, Spain

Krzysztof Goniewicz, Medical University of Warsaw, Poland

Loray Daws, British Columbia Masterson Institute, Canada

Marcel Wullschleger, University of Bern, Switzerland

Matteo Vitali, Hygiene at Sapienza University, Italy

Natasha AZZOPARDI MUSCAT, Maastricht University, Malta

Samir Othman, Hawler Medical University, Iraq

Sara Melo, Queen's University Belfast, United Kingdom

Srikrishna Sulgodu Ramachandra, Public Health Foundation of India, India

Thammanard Charernboon, Thammasat University, Thailand

Thanusin Saleeon, Ministry of Public Health, Thailand 